\title{
H3.X Gene
}

National Cancer Institute

\section{Source}

National Cancer Institute. H3.X Gene. NCI Thesaurus. Code C155735.

Human H3.X gene is located in the vicinity of 5p15.1 and is approximately $0.4 \mathrm{~kb}$ in length.

This pseudogene has no formally documented products. 